OPEN ACCESS

Edited by:

Staša Milojević,

Indiana University Bloomington,

United States

Reviewed by:

Enrique Orduna-Malea

Universitat Politècnica de València,

Spain

Jose A. Moral-Munoz,

University of Cádiz, Spain

*Correspondence:

Stanley I. R. Okoduwa

siroplc@gmail.com;

stanley@sironigeria.com

Received: 07 June 2018

Accepted: 21 August 2018

Published: 25 September 2018

Citation:

Okoduwa SIR, Abe JO, Samuel BI, Chris AO, Oladimeji RA, Idowu OO and Okoduwa UJ (2018) Attitudes,

Perceptions, and Barriers to Research and Publishing Among Research and Teaching Staff in a Nigerian Research Institute. Front. Res. Metr. Anal. 3:26.

doi: 10.3389/frma.2018.00026

\section{Attitudes, Perceptions, and Barriers to Research and Publishing Among Research and Teaching Staff in a Nigerian Research Institute}

\author{
Stanley I. R. Okoduwa ${ }^{1,2 \star}$, James O. Abe ${ }^{1}$, Blessing I. Samuel ${ }^{1}$, Aimee O. Chris ${ }^{1}$, \\ Richard A. Oladimeji ${ }^{1}$, Olanipekun O. Idowu ${ }^{3}$ and Ugochi J. Okoduwa ${ }^{2,3}$ \\ ${ }^{1}$ Directorate of Research and Development, Nigerian Institute of Leather and Science Technology, Zaria, Nigeria, \\ ${ }^{2}$ Information Technology Department, SIRONigeria Global Limited, Abuja, Nigeria, ${ }^{3}$ Petrochemicals and Allied Department, \\ National Research Institute for Chemical Technology, Zaria, Nigeria
}

The economic development of any nation is centered on research. Unfortunately, research activities had suffered serious setbacks in tertiary research institutions in Nigeria. This study explores the attitudes, perceptions, and barriers to research and publishing among academic staff in the Nigerian Institute of Leather and Science Technology, (NILEST) Zaria, Nigeria. A structured self-administered questionnaire was distributed among 130 research and teaching staff at the various Directorates in NILEST. Data are presented in frequencies and percentages for questionnaire responses. Exactly $94 \%$ of the questionnaires were validated for the study, which included $81 \%$ males and $19 \%$ females. The participants were researchers (26\%), lecturers (31\%), technologists (20\%), and instructors (22\%). The majority of participants agreed that research is important for the institute (91\%). A total of $81 \%$ believed that conducting research should be made mandatory for all academic staff. Only 44\% self-reported to be part of ongoing research. Some of the obstacles reported to have prevented research activities included a lack of funding (72\%), lack of professional mentorship (84\%), and inadequate research facilities (89\%). Participants without a single published paper constituted 57\%. Some of the reasons given for not having any published papers were "no writing experience (96\%), high publishing fee (80\%), and long waiting period for peer review (97\%)." The suggestions to improve research status by respondents included "provision of research grants/funds (93\%), provision of Internet facilities (95\%), mandatory publication (26\%), and appropriate mentorship (34\%)." The majority of the respondents believed that research is relevant; only a few were engaged in active research and published articles as evidence for it. It is, therefore, recommended that policymakers should devise strategies to focus on active research activities in order to achieve the desired research mandates and goals of institutions contributing to the development of the nation's economy.

Keywords: research, attitude, perception, barriers, publication, academic staff 


\section{INTRODUCTION}

Research is essentially the search for facts in the furtherance of knowledge. It involves the collation and analysis of information to improve the human understanding of phenomena under study (Bahadori et al., 2015). It entails data collection, analysis, interpretation, and assessment procedures conducted in a planned manner in order to find solutions to a problem (Burton and Walters, 2013; Rezaei and Miandashti, 2013). According to the Organization for Economic Cooperation and Development, research is the creative work that is undertaken on a systematic basis with the purpose of increasing knowledge, and to devise new applications [Organisation for Economic Coooperation and Development (OECD), 2002]. Research is frequently carried out in tertiary and research institutions (Hosseinpour, 2011; Kobova, 2014). In most cases, research staff and graduate students are the two main groups who conduct research, the rationale being that education in tertiary institutions requires students to submit research projects, theses, or dissertations for the fulfillment of a degree program. Previously, lecturers were not required to conduct research on the challenges they would encounter in the course of teaching and learning [Department of Health (DOH), 2006; Williams, 2013]. Much reliance has been placed on experts from diverse fields like psychology, philosophy, mathematics, and other sciences for the contents and execution of their teaching. As a result, the contribution to the field of teaching and learning from people, who were not trained as educators, has been significant and disproportionate (Thorndike, 1910).

Research was made at a university function in addition to the task of teaching in the late nineteenth century after the first academic revolution (Etzkowitz, 2003). Since then, attention to research is one of the most important issues in scientific communities (Bahadori et al., 2015). In recent years, research output emanating from academics has been assessed and used to rank universities against each other (Gross, 2004; Williams, 2013). Publishing of research work is evidence to justify support of research investigations and a guarantee of subsequent research funding for sustainability of the institute's mandate and organizational goals (Hegde et al., 2017).

The perceptions and attitudes of staff have significant impact on the success of an organization (Tsui et al., 1997; Garner and Hunter, 2013). More so, staff satisfaction toward research and publishing practices will enhance the developmental goal and strategic management of the institution and vice versa (Bhatti and Qureshi, 2007; Tella et al., 2007). The attitude and perception of staff toward research and publishing in the institution essentially depends on job satisfaction (Syed et al., 2012). Job satisfaction of staff, in turn, is influenced by research and publishing practices, research funding, research leave, research allowances, research training, and development compensation, availability of amenities, and professional mentorship (Tella et al., 2007; Garner and Hunter, 2013).

The attitude and perception of both teaching and research staff of many tertiary research institutions in Nigeria have been observed to be lackluster (Egbule, 2003; Chiemeke et al., 2009). Attitude and perception have significant impacts on staff performance, which, in turn, decides the performance of the organization. There is a need for the provision of the requirements of researchers, which would bolster their enthusiasm and improve their attitude and productivity (Murty and Fathima, 2013).

The Nigerian Institute of Leather and Science Technology (NILEST) is a specialized agency under the Federal Ministry of Science and Technology in Nigeria with the sole mandate "To provide courses of instruction, training, and research in the field of leather and leather product technology and conduct research and development on leather technologies and goods production" (NILEST in Brief, 2012). The visions of NILEST are "to become a research institute of international standard in the provision of innovative research and development in the processing and conversion of raw hides and skins into leather and leather products. Secondly, to be a renowned center of excellence in the field of tannery effluent monitoring and control, leather and leather products technologies and lastly, to be a center of excellence in the production of scientific models and polymer products." The workforce of the institute comprises both research and teaching staff employed to actualize the vision and core mandate of its establishment (NILEST in Brief, 2012). Unfortunately, after over 50 years of its inception coupled with the fact that the vast majority of Nigerians use leather and leather products in one way or another, the institute is virtually unknown (Okoduwa, 2017). Also, there is a paucity of published literature emanating from the institute on indexed journals, which is having a negative impact on its public profile. Possible explanations could be that research activities have been truncated for various reasons, which has a knock on effect on academic publications. It can be claimed that there is a direct relationship between conducting research and the actual progress of any institute of research. Previous studies conducted in other countries mention some barriers to research to include demographic characteristics and lack of resources for publication, and these were shown to affect the attitude and perception of staff toward research work and publications (Carrion et al., 2004; Hosenipour, 2012). The main objective of this study, therefore, focuses on the attitudes, perceptions, and barriers to research and academic publishing by the members of research and teaching staff in NILEST, Zaria, Nigeria. To the best of our knowledge, this is the first study of its kind to be conducted in NILEST.

\section{METHODS \\ Study Design}

This study was a cross-sectional descriptive survey using a structured questionnaire (Supplementary Data Sheet S1). The questionnaire covered age, sex, and significant attitudes and perceptions (identified through extensive literature searches as barriers to research and publishing). The questions were modified to suit the peculiar nature of the present case. The questionnaire was subdivided into different sections that included the perceptions of staff toward research, academic publishing, and subsequent effects on career development. Challenges and hindrances faced by staff were also queried and collated. Research assistants were trained in basic interviewing techniques. The questionnaire was pretested for flow of questions 
and for validity and was distributed at the Nigerian Institute of Leather and Science Technology (NILEST), headquarters, Zaria, North-West, Nigeria (located on latitude: $11^{\circ} 9^{\prime} 55.3^{\prime \prime}$ longitude: $7^{\circ} 39^{\prime} 5.84^{\prime \prime}$ ).

\section{Ethical Consideration}

The purpose of the study was explained to all the participants and a written informed consent was obtained from them. The study protocol was ethically approved by the Institutional Research and Academic Committee (NILEST/AREC/EA15/062) in accordance with the Helsinki declaration, and data confidentiality was assured.

\section{Selection Criteria}

Employees of NILEST headquarters, Zaria, Nigeria, who are either research or teaching staff, were selected and included for the study. Nonresearch, nonteaching, and administrative staff were excluded from the study.

\section{Data Source and Participants}

A total of 200 staff was enrolled for the study. They were randomly selected from all the departments and units in four main directorates at NILEST headquarters, Zaria, Nigeria. The study was conducted between December 1st, 2015 and May 30th, 2016.

Based on the inclusion criteria, the final sample consisted of 130 staff from four directorates, namely: Directorate of Leather Technology (DLT), Directorate of Polymer and Environmental Technology (DPET), Directorate of Research and Development (DRD), and Directorate of Science Laboratory Technology (DSLT). Participation was voluntary, and informed consent was obtained before distribution of questionnaires. The staff were given ample time to answer the questionnaires, after which the questionnaires were collected. Eight respondents returned incomplete questionnaires; these were considered invalid and excluded from the analysis. Only the completed questionnaires 122 (94\%) were considered valid and coded for analysis.

\section{Statistical Analysis}

The data obtained from the questionnaires were entered into Microsoft Excel 2013. Microsoft Excel and Statistical Package for Social Science (SPSS) software program (IBM SPSS v.20 Inc., Chicago Il, USA) were used for descriptive analysis of the data. The results are presented as percentages and frequency distribution.

\section{RESULTS}

\section{Demographic Characteristics of the Studied Participants}

The percentage distribution of respondents and their demographic characteristics are presented in Table 1 and Figure 1. A total of 122 staff participated in the study, including 23 females (19\%) and 99 males (81\%). The participants were drawn from four main directorates, as follows: $21 \%$ from DLT, $20 \%$ from DPET, $29 \%$ from DRD, and 30\% from DSLT.
TABLE 1 | Percentage distribution of respondents by designations and directorate.

\begin{tabular}{lccccc}
\hline Directorate & Instructor & Lecturer & Researcher & Technologist & Total \\
\hline DLT (\%) & 11 & 5 & 2 & 3 & 21 \\
DPET (\%) & 3. & 12 & 2 & 3 & 20 \\
DRD (\%) & 1 & 0 & 22 & 6 & 29 \\
DSLT (\%) & 7 & 15 & 0 & 8 & 30 \\
\hline Total (\%) & 22 & 32 & 26 & 20 & 100
\end{tabular}

Number of Participants = 122; DLT, Directorate of Leather Technology; DPET, Directorate of Polymer and Environmental Technology; DRD, Directorate of Research and Development; DSLT, Directorate of Science Laboratory Technology.

According to the designations of the participants as distributed in the four directorates, $26 \%$ were Researchers, $32 \%$ were Lecturers, and $42 \%$ were Technologists/Instructors. The majority of the participants $(43 \%)$ were within the age range of $31-40$ years. The lecturing cadre had the highest number with $31 \%$. The DSLT recorded the highest number of respondents (30\%). In terms of years of service, $65 \%$ of the participants were employees who had served the institute for $<10$ years. The researchers ranked highest (17\%) among the $<10$ years of service group. It was observed that only $35 \%$ of the participants had served the institute above 10 years. A total of $27 \%$ of the participants had various postgraduate qualifications such as M.Sc./Ph.D., while the majority (73\%) of the participants had only the basic first degree qualification such as B.Sc./HND (Figure 1).

\section{Barriers Encountered by Participants Toward Research and Publishing of Articles}

Some of the specified barriers encountered by the participants in conducting research and publishing of academic articles are presented in Figure 2 and Table 2. The identified barriers included lack of research funding $(72 \%)$, inadequate research facilities (89\%), inadequate training/orientation programs (52\%), and lack of mentorship (84\%). Among the various categories of respondents, $84 \%$ of Researchers reported lack of funds as a barrier hindering research activities and publishing of article among them. More than $80 \%$ of each category of respondents reported inadequate research facilities as the most significant issue. About half of the Instructors (48\%) reported inadequate research experience as the most challenging barrier toward research and publishing. Lack of training and orientation programs was reported by over half of the Researchers (66\%) and Technologists (56\%). Lack of professional mentorship was also reported by more than $70 \%$ of each category of respondents. It was observed that the majority of respondents (79\%) have never benefitted from research grants. Only a few of the participants (15\%) had benefitted from publication fees assistance/waiver. None of the Instructors and Technologists have ever benefitted from publication fee assistance. Limited numbers of the Lecturers (4\%) and Researchers (11\%) reported that they have benefitted from publication fee assistance. 


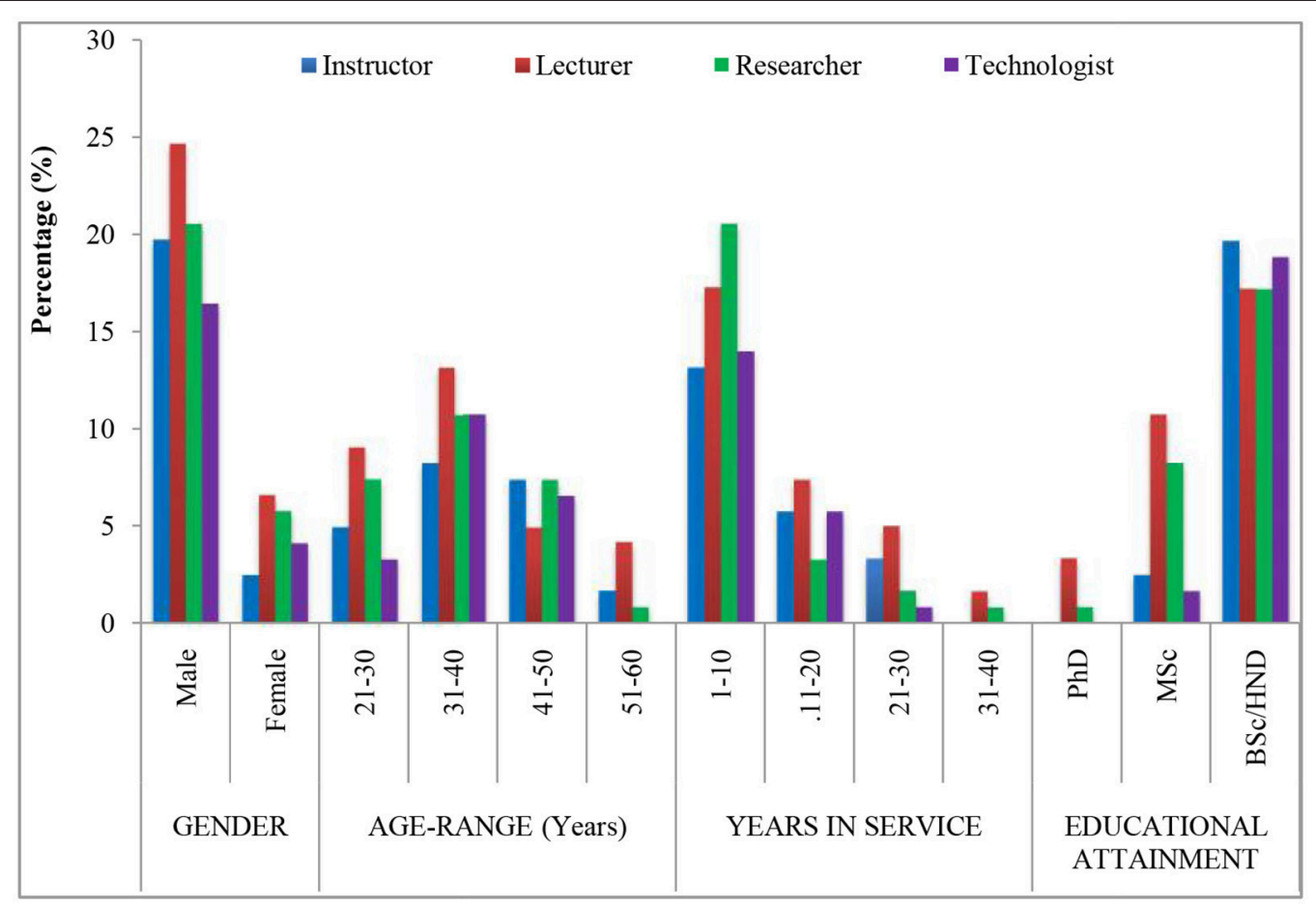

FIGURE 1 | Demographic characteristics of respondents.

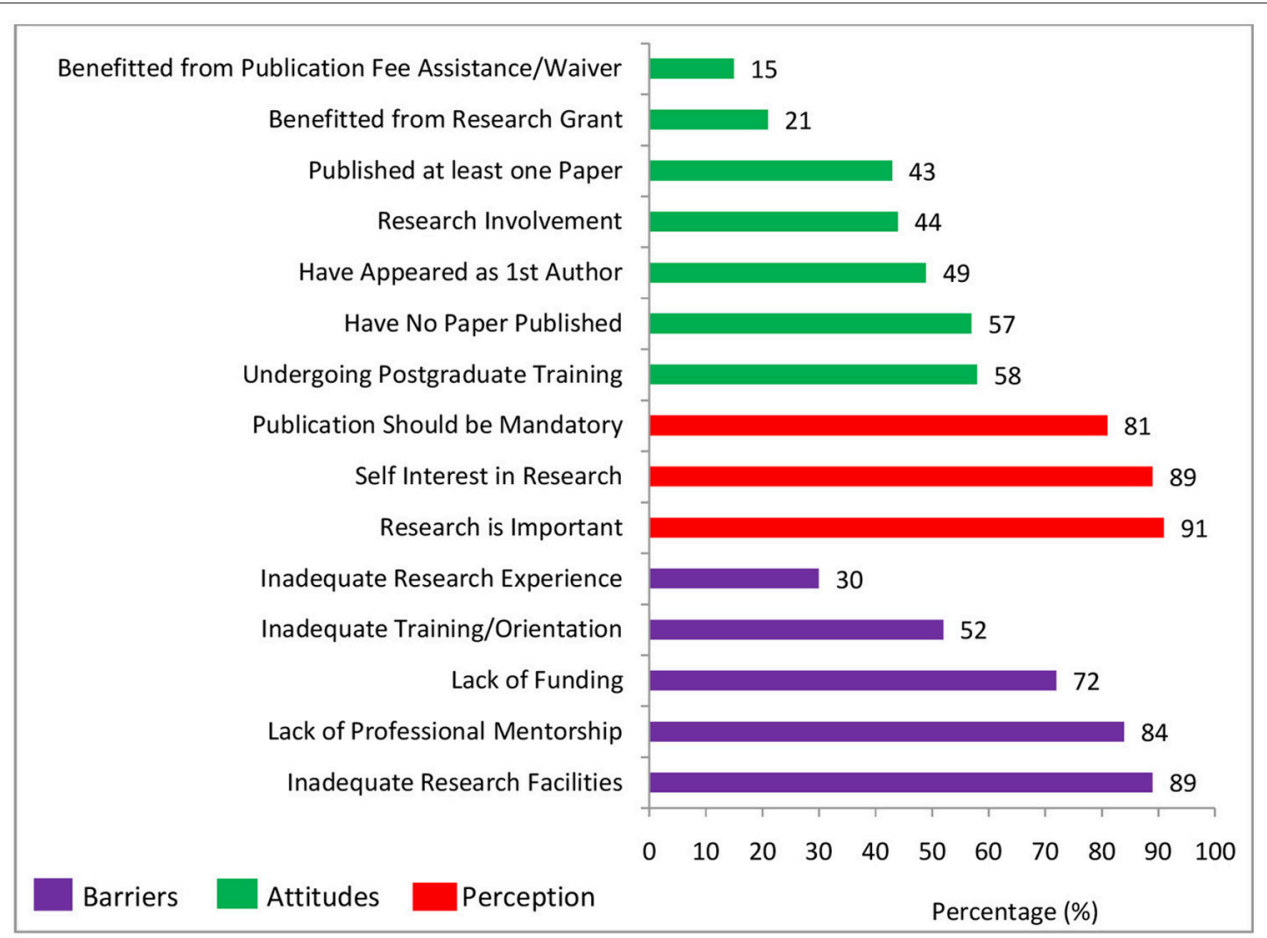

FIGURE 2 | An overview of barriers, attitudes, and perception of entire participants toward research and publishing of articles. 
TABLE 2 | Barriers toward conducting research and publishing of articles that are specific among the different cadres of respondents.

\begin{tabular}{|c|c|c|c|}
\hline Category & Respondents & Frequency & Percentage (\%) \\
\hline \multirow[t]{4}{*}{ Lack of fund (72\%) } & Instructors & 20 & 74 \\
\hline & Lecturers & 29 & 76 \\
\hline & Researchers & 27 & 84 \\
\hline & Technologists & 12 & 48 \\
\hline \multirow{4}{*}{$\begin{array}{l}\text { Inadequate research } \\
\text { facilities (89\%) }\end{array}$} & Instructors & 22 & 81 \\
\hline & Lecturers & 36 & 95 \\
\hline & Researchers & 28 & 88 \\
\hline & Technologists & 23 & 92 \\
\hline \multirow{4}{*}{$\begin{array}{l}\text { Inadequate research } \\
\text { experience (30\%) }\end{array}$} & Instructors & 13 & 48 \\
\hline & Lecturers & 10 & 26 \\
\hline & Researchers & 6 & 19 \\
\hline & Technologists & 7 & 28 \\
\hline \multirow{4}{*}{$\begin{array}{l}\text { Lack of } \\
\text { training/orientation (52\%) }\end{array}$} & Instructors & 12 & 44 \\
\hline & Lecturers & 17 & 45 \\
\hline & Researchers & 21 & 66 \\
\hline & Technologists & 14 & 56 \\
\hline \multirow{4}{*}{$\begin{array}{l}\text { Lack of professional } \\
\text { mentorship (84\%) }\end{array}$} & Instructors & 25 & 93 \\
\hline & Lecturers & 27 & 71 \\
\hline & Researchers & 29 & 91 \\
\hline & Technologists & 22 & 88 \\
\hline \multirow{4}{*}{$\begin{array}{l}\text { Benefitted from } \\
\text { publication fees } \\
\text { assistance/waiver (15\%) }\end{array}$} & Instructors & 00 & 0 \\
\hline & Lecturers & 02 & 4 \\
\hline & Researchers & 06 & 11 \\
\hline & Technologists & 00 & 0 \\
\hline \multirow{4}{*}{$\begin{array}{l}\text { Benefitted from research } \\
\text { grant }(21 \%)\end{array}$} & Instructors & 2 & 4 \\
\hline & Lecturers & 7 & 13 \\
\hline & Researchers & 2 & 4 \\
\hline & Technologists & 0 & 0 \\
\hline
\end{tabular}

\section{Perceptions of Participants to Research and Publishing of Articles}

The perception of respondents to research and publishing is presented in Figure 2 and Table 3 . The majority of participants (91\%) agreed that research and publishing is important for academic and economic development. From the perspective of the different groups of respondents, it was observed that all the Researchers concurred to the fact that research is important. More so, $89 \%$ of Instructors, $92 \%$ of Lecturers, and $80 \%$ of the Technologists consented to the significance of research in increasing the research status of the institution and development of the nation's economy. The majority of the respondents (81\%) have the same opinion that the conducting of research and publishing of articles should be mandatory for all staff. Among these groups were 67\% Instructors, 76\% Lecturers, 97\% Researchers, and $84 \%$ Technologists.
TABLE 3 | Attitudes and perceptions toward conducting research and publishing of articles that are specific among the different cadres of respondents.

\begin{tabular}{|c|c|c|c|}
\hline Category & Respondents & Frequency & Percentage (\%) \\
\hline \multirow{4}{*}{$\begin{array}{l}\text { Self interest in research } \\
(89 \%)\end{array}$} & Instructors & 19 & 70 \\
\hline & Lecturers & 36 & 95 \\
\hline & Researchers & 31 & 97 \\
\hline & Technologists & 23 & 92 \\
\hline \multirow{4}{*}{$\begin{array}{l}\text { Research is important } \\
(91 \%)\end{array}$} & Instructors & 24 & 89 \\
\hline & Lecturers & 35 & 92 \\
\hline & Researchers & 32 & 100 \\
\hline & Technologists & 20 & 80 \\
\hline \multirow{4}{*}{$\begin{array}{l}\text { Research/publication } \\
\text { should be mandatory } \\
(81 \%)\end{array}$} & Instructors & 18 & 67 \\
\hline & Lecturers & 29 & 76 \\
\hline & Researchers & 31 & 97 \\
\hline & Technologists & 21 & 84 \\
\hline \multirow{4}{*}{$\begin{array}{l}\text { Research involvement } \\
(44 \%)\end{array}$} & Instructors & 6 & 22 \\
\hline & Lecturers & 13 & 34 \\
\hline & Researchers & 24 & 75 \\
\hline & Technologists & 11 & 44 \\
\hline \multirow{4}{*}{$\begin{array}{l}\text { Ongoing postgraduate } \\
\text { training (58\%) }\end{array}$} & Instructors & 15 & 56 \\
\hline & Lecturers & 21 & 55 \\
\hline & Researchers & 25 & 78 \\
\hline & Technologists & 10 & 40 \\
\hline \multirow{4}{*}{$\begin{array}{l}\text { Published at least one } \\
\text { paper (43\%) }\end{array}$} & Instructors & 5 & 19 \\
\hline & Lecturers & 20 & 53 \\
\hline & Researchers & 22 & 69 \\
\hline & Technologists & 6 & 24 \\
\hline \multirow{4}{*}{$\begin{array}{l}\text { Have no paper published } \\
(57 \%)\end{array}$} & Instructors & 13 & 48 \\
\hline & Lecturers & 21 & 55 \\
\hline & Researchers & 25 & 78 \\
\hline & Technologists & 10 & 40 \\
\hline \multirow{4}{*}{$\begin{array}{l}\text { Have appeared as 1st } \\
\text { author (49\%) }\end{array}$} & Instructors & 3 & 11 \\
\hline & Lecturers & 9 & 24 \\
\hline & Researchers & 12 & 38 \\
\hline & Technologists & 2 & 8 \\
\hline
\end{tabular}

\section{Attitude of Participants to Research and Publishing of Articles}

The self-reported attitudes of respondents to research and publishing are presented in Figure 2 and Table 3. Although the majority of respondents (89\%) reported that they have self-interests in research (out of which $97 \%$ were Researchers, 92\% were Technologists, and 95\% Lecturers, and 70\% were Instructors), it was, however, amazing to observe that only $44 \%$ 


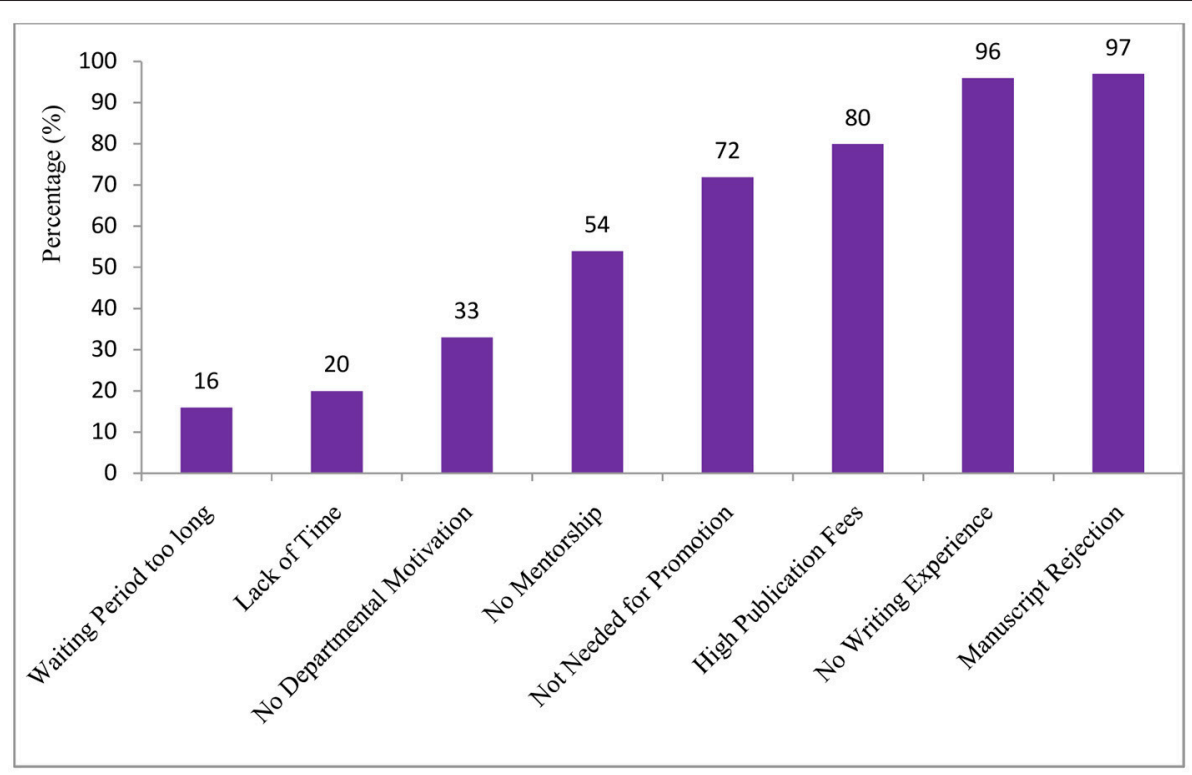

FIGURE 3 | Reasons for not publishing by participants without published article. NB, Values presented are in percentages.

of the participants were involved in ongoing research. Among the participants involved in active research were $75 \%$ of Researchers.

More than half (58\%) of the Researchers, Instructors, and Lecturers were undergoing various postgraduate training such as M.Sc. and Ph.D. programs. Interestingly, only $43 \%$ of the participants have published at least one academic article in a peer reviewed journal. Among these were 69\% of Researchers and $53 \%$ of Lecturers. Regrettably, 57\% of all the respondents have never published any paper in academic peer reviewed indexed journals. Among those that have published at least one academic paper in peer reviewed journals, only $49 \%$ have appeared as first author in those articles, of which $38 \%$ were the Researchers.

Those who reported they had not published articles were questioned further as to why they had not. Some of the respondents (16\%) said it was due to a long waiting period for the peer review process. About 20\% reported they had no time to write an article for publication due to other commitments, while $33 \%$ said it was due to a lack of departmental motivation to conduct research and consider publishing the outcome of the research. A large number (97\%) said due to rejection of manuscript upon submission for publication consideration, $96 \%$ said they had no writing experience, and $80 \%$ said it was due to the high publication fee for publishing articles (Figure 3).

About half (54\%) of the respondents in the group said they had no mentorship on how to process manuscripts for peer review indexed journals. Surprisingly, about $72 \%$ of those without published articles said it was not needed for their promotion/career growth (Figure 3).

Those who have published at least one paper or submitted manuscript for publication consideration reported their main motivation to be career development, information relay, and self-interest (Figure 4).

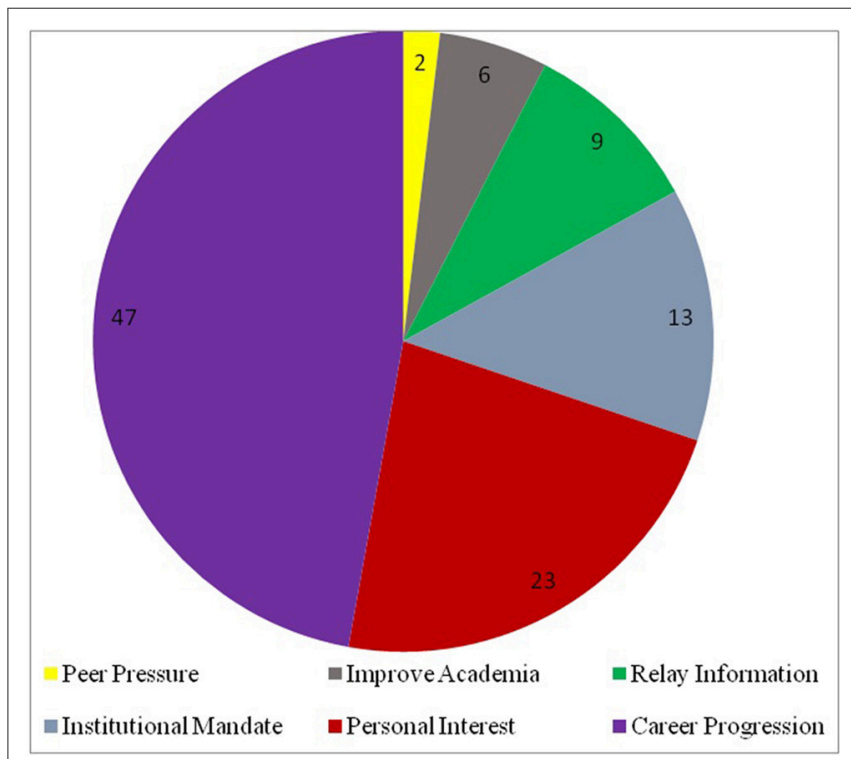

FIGURE 4 | Reasons for publishing by participants with at least one published article. NB, Values presented are in percentages.

\section{Suggestions to Improve the Status of Research and Publishing in Tertiary Institutions}

Suggestions collated from the participants that could help improve the status of research and publishing are presented in Figure 5. These included provision of research grants and publication fee assistance and special award of excellence for 


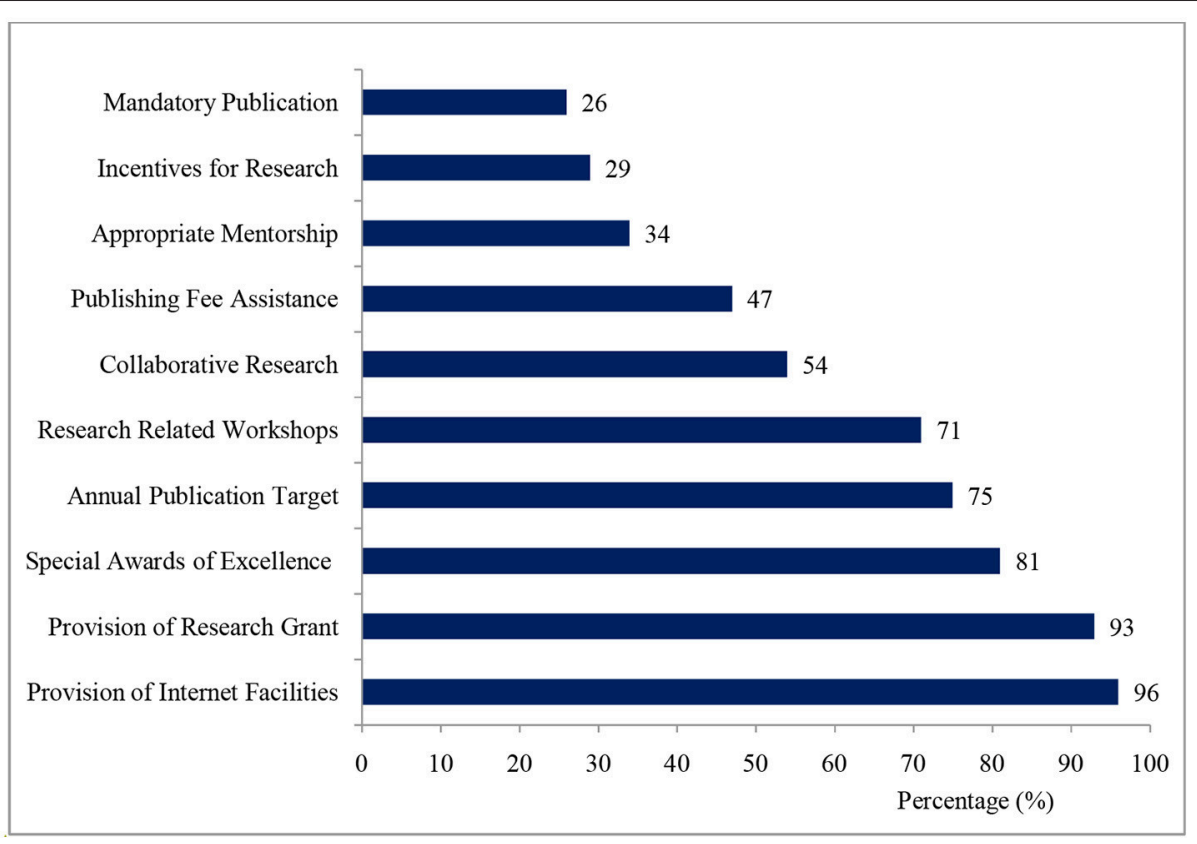

FIGURE 5 | Suggestions by participants for improving the status of research and publishing.

outstanding contributions to deserving staff and provision of Internet facilities.

\section{DISCUSSION}

This study revealed a great disparity between the participation in and attitudes toward research activities and publication of scholarly articles among research and teaching staff in NILEST, as well as significant barriers impeding these activities. Some of these have been reported by other investigators (Corbin and Strauss, 2008; Williams, 2013; Jahan et al., 2015; Hegde et al., 2017) such as lack of adequate facilities, skills, and personal interest. To the best of our knowledge, this is the first study of its kind to examine the barriers, perceptions, and attitudes of staff toward research and/or academic publishing in NILEST. The overall response of staff was encouraging, the initial reluctance of a sizable proportion of the staff notwithstanding.

Although gender equality is an imperative consideration globally (Cornwall and Rivas, 2015; Jewkes et al., 2015), this study showed that the number of males working as research/teaching staff was higher compared with females in the entire directorate investigated (Figure 1). Among the female staff, involvement in research was notably lower compared with males. This observation is similar to some studies conducted in the United States, one of which cites low self-ability as a major barrier toward participation in research activities. However, no discrete reason was recognized in our study to elucidate this observation. On the other hand, this difference may be due to the cultural, religious, and social expectations and responsibilities faced by females in this part of the world (Mordi et al., 2010; Para-Mallam, 2010).
The majority of respondents in our study had been in active service with the institute for $<10$ years. This may be due to a change in the name of the institute that properly repositioned it in line with its mandate, mission, and vision, which occurred on 1st April 2011 (7 years ago) (NILEST in Brief, 2012; Olatunji et al., 2015). This change brought an influx of research-oriented staff, in line with the new research capable status of the institute (it was previously a college). It was earlier reported that there were just 2 Ph.D. and few numbers of M.Sc. holders as of 2009. But, after the change in name from CHELTECH to NILEST, the numbers increased to 7 Ph.D. and 15 M.Sc. holders excluding additional 5 Ph.D. and 7 M.Sc. staff in training as of 2012 (NILEST in Brief, 2012).

A probable reason for the observed decline in staff strength as the years of service increase may be a lack of job satisfaction, leading to transfers of service to perceived greener pastures. This is most likely responsible for the dearth of Ph.D. holders in the institute, as upon attainment of higher qualifications, there is the urge to transfer service to universities where staff may be better placed and accorded portfolios befitting their status. This may include professorial seats and administrative or political positions. This observation may be supported by the fact that more than half (58\%) of the participants were engaged in various postgraduate programs, yet only a few $(<5 \%)$ hold a doctorate degree as of the time of this investigation. In the Nigerian system, it takes around 10 years for a civil/public servant to acquire a doctorate [2-year confirmation, 2-year study leave (M.Sc.), 2-year waiting period, 3 -years study leave (Ph.D.)]. The greener pastures beckon thereafter.

Some other barriers to research activities identified by this study have been described by other investigators elsewhere 
(Aslam et al., 2005; Dickson-swift et al., 2006; Baro and Ebhomeya, 2012). These include lack of suitably qualified mentors with appropriate expertise and sufficient time for mentoring, limited resources such as funds and facilities, and logistical difficulties. In all, lack of support from the institution and inappropriate funding of research activities are the hallmarks of failure to execute research tasks. Besides these, the limited number of research mentors is one of the barriers claimed by some of the respondents in this study. Lack of mentorship contributes to the inadequate research experience confronting the staff (Nykamp et al., 2010; Al-Ghamdi et al., 2014; Oliveira et al., 2014; Kharraz et al., 2016). Lack of professional mentorship is put forth as an incredibly strong theme predominantly for new members of academic staff in this study who acknowledged the need for guidance in commencing research works. Positive role models and adequate professional mentorship are crucial to researchers and, if unsupported, early career staff can discontinue their work (Aslam et al., 2005). It would be rational to believe that the best mentor would be an experienced researcher with track record of publications. This observation was in harmony with the report of Williams (2013) on the need for new researchers to have a mentor who can guide them through the process of research and publishing of scholarly articles. Unfortunately, this practice is only obtainable in tertiary institutions where research is part of students' academic program of study (Dickson-swift et al., 2006).

The majority of the respondents (91\%) agreed that it was imperative to publish papers. This observation is consonant with reports from previous investigators on related subjects (Srinivasan et al., 2014; Hegde et al., 2017). All the Researchers included in this study felt that research activities and publishing are mandatory for career progression, a condition of service for research institutions in Nigeria. This is contrary to the conditions of service in use by the teaching staff in NILEST that provides no recognition for research activities and academic publications. The respondents' interest toward research and reasons for which scholarly publication was considered valuable included improving their relationships with and gaining respect from fellow colleagues in the scientific community, advancing their career opportunities, and improving their writing and research skills. These observations were similar to that reported by Griffin and Hindocha (2011). Research skills for teaching staff are becoming imperative, particularly for obtaining designated positions in competitive markets, and in order to secure research grants (Tracey et al., 1995). Aside research staff, teaching staff can be potential contributors to scientific research and development through participation in different commercially oriented research (Martin, 1997; Shamai and Kfir, 2002). It is noted in this study that less than half of the respondents (44\%) reported scholarly research publications as a means to improve the relationship with and gain respect from scientific community, as well as recuperating their writing and research skills.

For those that had not published at least one article, it is clear that the main barrier was not having the opportunity to perform research as they were not engaged in any research activities in the first instance; hence, they feel they have nothing to declare as a publication. This was also in agreement with the findings reported by Griffin and Hindocha (2011). A survey of Australian researchers showed that research infrastructure support is vital to research productivity (Shewan et al., 2002).

In this study, $81 \%$ of the respondents have suggested that research and publishing should be made mandatory for all academic and research staff (Table 3). Mandatory involvement in research activities has been demonstrated to improve researchers' attitude toward research (Segal et al., 1990).

Lack of time is another factor militating against the conducting of research and also one major hindrance to accessing research funds (Baro and Ebhomeya, 2012). According to Yusuf (2012) the declining research productivity in the Nigerian university system is attributed to among other factors the "rising workloads associated with deteriorating staff/students ratio," which leave little time for research. Lack of knowledge about funding agencies/organization, bureaucracy in the acquisition of funds, and the exclusion of research institutes from Education Trust Fund by the 2011 Tertiary Education Trust Fund (TETFund) Acts, in which section 20 of the Act was responsible for deterring researchers from conducting meaningful research (Bello, 2012; Baro et al., 2017). These observations were in agreement with the findings by Dorsey et al. (2013) that government policies on budgets to researchers deter implementation and conducting of research.

Due to the anonymous nature of the present research, the likelihood of bias is reduced. This does not sideline the significant limitation, which needs to be highlighted. The present study was conducted in a single research institute; hence, may be insufficient when one has to generalize.

\section{CONCLUSION}

In conclusion, this study highlights clearly that less than half of the studied population were involved in active research activities and had published at least one article. This can be improved by providing more accessible opportunities to take part in research followed by encouragement and guidance from professional mentors. More opportunities to perform research and teaching will aid academic staff to increase their publishing potential. Hence, the management of the institute and policymakers may consider taking special research initiatives to address the barriers and improve the involvement of academic staff in scholarly active research activities and publishing.

The results of this study could be the basis for similar future comparative studies and policy formulations that may promote the research mandate of every institution in order to achieve their organizational goal to enhance the nation's economic development, security, and sustainability. Further study is therefore recommended at different research institutions on a larger sample size.

\section{AUTHOR CONTRIBUTIONS}

SO got the concept, design, and interpretation of the study. JA, $\mathrm{BS}, \mathrm{AC}$, and $\mathrm{RO}$ conducted the field study and management of questionnaires. SO, OI, and UO drafted the manuscript and participated in data analysis and literature search. SO 
and OI critically reviewed and revised the manuscript for important intellectual content. All authors read through the final version of the manuscript and gave consent for its publication.

\section{ACKNOWLEDGMENTS}

This research did not receive any specific grant from funding agencies in the public, commercial, or not-for-profit sectors. The

\section{REFERENCES}

Al-Ghamdi, K. M., Moussa, N. A., Al-Essa, D. S., Al-Othimeen, N., and Al-Saud, A. S. (2014). Perceptions, attitudes and practices towards research among senior medical students. Saudi Pharm J. 22, 113-117. doi: 10.1016/j.jsps.2013.02.006

Aslam, F., Shakir, M., and Ahad-Qayyum, M. (2005). Why medical students are crucial to the future of Research in South Asia. PLoS Med. 2:e322. doi: 10.1371/journal.pmed.0020322

Bahadori, M., Momeni, K., Ravangard, R., Yaghoubi, M., Alimohammadzadeh, K., Teymourzadeh, E., et al. (2015). Challenges of the health research system in a medical research institute in iran: a qualitative content analysis. Glob. J. Health Sci. 7, 69-78. doi: 10.5539/gjhs.v7n1p69

Baro, E. E., Bosah, G. E., and Obi, I. C. (2017). Research funding opportunities and challenges: a survey of academic staff members in Nigerian tertiary institutions. Bottom Line 30, 447-644. doi: 10.1108/BL-07-2016-0027

Baro, E. E., and Ebhomeya, L. A. (2012). A comparative study of the publication output of librarians and academics in universities in the south-south zone of Nigeria. J. Sch. Publ. 43, 200-219. doi: 10.3138/jsp.43.2.200

Bello, T. O. (2012). Funding for research in science and technology in Nigerian universities: the gender perspective. J. Emerg. Trends Educ. Res. Policy Stud. 3, 34-38.

Bhatti, K. K., and Qureshi, T. M. (2007). Impact of employee participation on job satisfaction, employee commitment, and employee productivity. Int. Rev. Bus. Res. Pap. 3, 54-68.

Burton, H., and Walters, L. (2013). Access to medicare-funded annual comprehensive health assessments for rural people with intellectual disability. Rural Remote Health 13:2278. Available Online at: www.rrh.org.au/journal/ article $/ 2278$

Carrion, M., Woods, P., and Norman, I. (2004). Barriers to research utilization among forensic mental health nurses. Int. J. Stud. 41, 613-619. doi: 10.1016/j.ijnurstu.2004.01.006

Chiemeke, S., Longe, O. B., Longe, F. A., and Shaib, I. O. (2009). Research outputs from Nigerian tertiary institutions: an empirical appraisal. Library Philos. Pract. $233,1-10$.

Corbin, J., and Strauss, A. (2008). Basics of Qualitative Research, 3rd Edn. London: Sage.

Cornwall, A., and Rivas, A. M. (2015). From gender equality and women's empowerment to global justice: reclaiming a transformative agenda for gender and development. Third World Q. 336, 396-415. doi: 10.1080/01436597.2015.1013341

Department of Health (DOH) (2006). Best Research for Best Health a New National Health Research Strategy. London: DOH.

Dickson-swift, V., James, E. L., Kippen, S., and Liamputtong, P. (2006). Blurring the boundaries in qualitative health research on sensitive topics. Qual. Res. 16, 853-871. doi: 10.1177/1049732306287526

Dorsey, S., Pullmann, M. D., Deblinger, E., Berliner, L., Kerns, S. E., Thompson, K., et al. (2013). Improving practice in community-based settings: a randomized trial of supervision-study protocol. Implement. Sci. 8:89. doi: $10.1186 / 1748-5908-8-89$

Egbule, P. E. (2003). Factors related to job satisfaction of academic staff in Nigerian universities. J. Furth. High. Educ. 27, 157-166. doi: 10.1080/0309877032000065172

Etzkowitz, H. (2003). Research groups as 'quasi-firms': the invention of the entrepreneurial university. Res. Policy 32, 109-121. doi: $10.1016 /$ S0048-7333(02)00009-4 authors express their warm appreciation to the Dr. A. Ejila, Director of Research, NILEST, Zaria, Nigeria for approval to conduct the study.

\section{SUPPLEMENTARY MATERIAL}

The Supplementary Material for this article can be found online at: https://www.frontiersin.org/articles/10.3389/frma. 2018.00026/full\#supplementary-material
Garner, B. R., and Hunter, B. D. (2013). Examining the temporal relationship between psychological climate, work attitude and staff turnover. J. Subst. Abuse Treat. 44, 193-200. doi: 10.1016/j.jsat.2012.05.002

Griffin, M. F., and Hindocha, S. (2011). Publication practices of medical students at British medical schools: experience, attitudes and barriers to publish. Med. Teach. 33, e1-e8. doi: 10.3109/0142159X.2011.530320

Gross, I. (2004). An impact Assessment of the Funding Bodies Proposals for Research Assessment. HEFCE Assurance Service Available online at: http://www.rae.ac. uk/pubs/other/impact/ (Accessed September 04, 2010).

Hegde, A., Venkataramana, G., Kulkarni, S. B., Bhaskar, N. N., Jacob, J., and Gangadharappa, S. K. (2017). Attitudes, experiences, and barriers to research and publishing among dental postgraduate students of Bengaluru city: a cross-sectional study. J. Indian Assoc. Public Health Dent. 15, 157-161. doi: 10.4103/jiaphd.jiaphd_11_17

Hosenipour, M. (2012). The pathology research faculty of human sciences. Knowl. Stud. Islamic Univ. 16, 45-64.

Hosseinpour, M. (2011). A study of debilitating factors of research from the viewpoint of faculty members in human sciences. New Find. Psychol. 6, 79-95.

Jahan, F., Al-Mabali, A., Siddiqui, M. A., and Al-Zadjali, N. M. (2015) Attitude and barriers towards research amongs health care professionals working in primary care services of oman. Health Educ. Res. Dev. 3:144. doi: 10.4172/2380-5439.1000144

Jewkes, R., Flood, M., and Lang, J. (2015). From work with men and boys to changes of social norm and reduction of inequalities in gender relations: a conceptual shift in prevention of violence against women and girls. Lancet 385, 1580-1589. doi: 10.1016/S0140-6736(14)61683-4

Kharraz, R., Hamadah, R., AlFawaz, D., Attasi, J., Obeidat, A. S., Alkattan, W., et al. (2016). Perceived barriers towards participation in undergraduate research activities among medical students at Alfaisal University-College of Medicine: a Saudi Arabian perspective. Med. Teach. 38, S12-S18. doi: 10.3109/0142159X.2016.1142507

Kobova, L. (2014). Knowledge production in European Universities. Hum. Affairs 24, 148-150. doi: 10.2478/s13374-014-0213-1

Martin, G. A. (1997). Teachers or researchers? The perception of professional role among university lecturers. Program. Learn. 34, 154-159. doi: 10.1080/1355800970340211

Mordi, C., Simpson, R., Singh, S., and Okafor, C. (2010). The role of cultural values in understanding the challenges faced by female entrepreneurs in Nigeria. Gender Manage. 25, 5-21. doi: 10.1108/17542411011019904

Murty, T. N., and Fathima, F. (2013). Peception and attitude of employees towards training and development in public sector unit. Int. Month. Refer. J. Res. Manage. Technol. 2, 141-147.

NILEST in Brief (2012). Brief history of the Nigerian Institute of Leather and Science Technology, Federal Ministry of Science and Technology, Samara, Zaria Nigeria. Zara: Salfik Print Limited.

Nykamp, D., Murphy, J. E., Mashall, L. L., and Bell, A. (2010). Pharmacy students' participation in a research experience culminating in journal publication. Am. J. Pharm. Educ. 74:47.

Okoduwa, S. I. R. (2017). Promoting the vision and research mandate of institutions through mobile technology in the $21^{\text {st }}$ century: Case study "NILEST Mobile-App". Int. J. Adv. Res. Public. 1, 138-140.

Olatunji, T. E., Daniel, B. B., Ibrahim, I., Hannatu, M., and Jonathan, B. (2015). Conflict management in organization: trends and issues at the Nigerian Institute of Leather and Science Technology, Zaria, Nigeria. Int. Policy Brief Ser. $5,12-23$ 
Oliveira, C. C., de-Souza, R. C., Abe, É. H. S., Silva-Móz, L. E., de-Carvalho, L. R., and Domingues, M. A. (2014). Undergraduate research in medical education: A descriptive study of students' views. BMC Med. Educ. 14:51. doi: 10.1186/1472-6920-14-51

Organisation for Economic Coooperation and Development (OECD) (2002). Frascati Manual. 2002. Proposed Standard Practice for Surveys on Research and Experimental Development, 6th Edn. Paris: OECD Publishing.

Para-Mallam, F. J. (2010). Promoting gender equality in the context of Nigerian cultural and religious expression: beyond increasing female access to education. Compare 440, 459-477. doi: 10.1080/03057925.2010.490370

Rezaei, M., and Miandashti, N. Z. (2013). The relationship between research selfefficacy, research anxiety and attitude toward research: a study of agricultural graduate students. J. Educ. Instruct. Stud. World 3, 2146-7463.

Segal, S., Lloyd, T., Houts, P. S., Stillman, P. L., and Jungas, R. L. (1990). The association between students' research involvement in medical school and their postgraduate medical activities. Acad. Med. 65, 530-533.

Shamai, S., and Kfir, D. (2002). Research activities and research culture in academic teachers. Teach. High. Educ. 7, 397-410. doi: 10.1080/135625102760553900

Shewan, L. G., Glatz, J. A., Bennert, C., and Coats, A. J. (2002). Contemporary (post wills) survey of the views of Australian medical researchers: Importance of funding, infrastructure and motivators for a research career. Med. J. Aust. 177, 74-77.

Srinivasan, M. R., Poorni, S., Sujatha, G., and Kumar, S. N. (2014). Research experiences, attitudes and barriers to publishing among dental postgraduate teachers. A cross sectional study. Indian J. Dent. Res. 25, 454-458. doi: 10.4103/0970-9290.142529

Syed, A. A. S. G., Anka, L. M., Jamali, M. B., and Shaikh, F. M. (2012). Motivation as a tool for effective staff productivity in the public sector. A case study of the raw materials research and development council of Nigeria. Asian Soc. Sci. 8, 85-95.

Tella, A., Ayeni, C. O., and Popoola, S. O. (2007). Work motivation, job satisfaction and organizational commitment of library personnel in academic and research libraries in Oyo State, Nigeria. Library Philos. Pract. 118, 1-16.

Thorndike, E. L. (1910). The contribution of psychology to education. J. Educ. Psychol. 1, 5-12.

Tracey, J. B., Tannenbaum, S. I., and Kavanagh, M. J. (1995). Applying trained skills on the job: the importance of the work environment. J. Psychol. 80:239.

Tsui, A. S., Pearce, J. L., Porter, L. W., and Tripoli, A. M. (1997). Alternative approaches to the employee-organisation relationship: does investment in employees pay off? Acad. Manage. J. 40, 1089-1121.

Williams, C. (2013). Attitudes to and perceptions of research for health lecturers. Radiography 19, 56-61. doi: 10.1016/j.radi.2012.08.003

Yusuf, A. K. (2012). An appraisal of research in Nigeria universities sector. J. Res. Natl. Dev. 10, 321-330

Conflict of Interest Statement: The authors declare that the research was conducted in the absence of any commercial or financial relationships that could be construed as a potential conflict of interest.

Copyright (C) 2018 Okoduwa, Abe, Samuel, Chris, Oladimeji, Idowu and Okoduwa. This is an open-access article distributed under the terms of the Creative Commons Attribution License (CC BY). The use, distribution or reproduction in other forums is permitted, provided the original author(s) and the copyright owner(s) are credited and that the original publication in this journal is cited, in accordance with accepted academic practice. No use, distribution or reproduction is permitted which does not comply with these terms. 